\title{
KEEFEKTIFAN MODEL PEMBELAJARAN KOOPERATIF TEAMS ASSISTED INDIVIDUALIZATION DENGAN MACROMEDIA AUTHORWARE MATERI SEGI EMPAT KELAS VII SMPN 3 KUDUS
}

\author{
Savitri Wanabuliandari \\ Program Studi Pendidikan Guru Sekolah Dasar \\ Email : vhee.three@yahoo.co.id
}

\begin{abstract}
ABSTRAK
Tujuan dari penelitian ini adalah (1) untuk mengetahui rata-rata hasil belajar matematika peserta didik yang menggunakan model pembelajaran kooperatif TAI dengan Macromedia Authorware lebih baik daripada pembelajaran tanpa Macromedia Authorware pada materi pokok segiempat pada peserta didik kelas VII SMP Negeri 3 Kudus dan (2) untuk mngetahui hasil belajar matematika peserta didik yang menggunakan model pembelajaran kooperatif TAI dengan Macromedia Authorware pada materi pokok segiempat pada peserta didik kelas VII SMP Negeri 3 Kudus akan melampaui ketuntasan klasikal yang telah ditetapkan oleh sekolah yaitu yaitu minimal $80 \%$ hasil belajar peserta didik mencapai 67.

Berdasarkan hasil analisis rata-rata hasil belajar kelas eksperimen adalah 81,05 dan kelas kontrol $68,34, t_{\text {hitung }}=4,254$ dan $t_{\text {tabel }}=1,99$ sehingga rata-rata hasil belajar kelas eksperimen lebih baik dibandingkan kelas kontrol. Selanjutnya dari hasil perhitungan diperoleh $Z_{\text {hitung }}=1,976423544$ dan $Z_{\text {tabel }}=1,64$ sehingga hasil belajar peserta didik melampaui ketuntasan klasikal yaitu minimal $80 \%$ hasil belajar peserta didik mencapai 67.
\end{abstract}

Kata kunci: TAI, Macromedia Authorware

\begin{abstract}
Purpose of this study is (1) to determine that the average of the mathematics learning result of the learners who use the model of TAI cooperative learning with Macromedia Authorware is better than learning without Macromedia Authorware in the main subject of square of the seventh grade learner of SMP Negeri 3 Kudus and (2) to know the mathematics learning result of the learners who use the model of TAI cooperative learning with Macromedia Authorware in the main subject of the seventh grade learner of SMP Negeri 3 Kudus will passes over the classical completeness which is minimum $80 \%$ of the learners result reached 67.

Based on analysis of the average learning results of experimental class is 81,05 and control class is 68,34, $t=4,254$ and ttable $=1,99$ so the average learning results of experimental class is better than control class. Furthermore, from the calculations, Zhitung $=1.976423544$ and Ztabel $=1.64$ so the learners learning result passes over the classical completeness which is minimum $80 \%$ of the learners learning result reached 67.
\end{abstract}




\section{PENDAHULUAN}

Matematika sebagai salah satu pelajaran dalam dunia pendidikan dikenal sebagai pelajaran yang tidak terlalu mudah dipahami oleh peserta didik. Sebagian peserta didik merasa takut kepada mata pelajaran matematika padahal pelajaran matematika diberikan di semua sekolah, baik dijenjang pendidikan dasar maupun pendidikan menengah. Matematika sangat diperlukan untuk kehidupan sehari-hari maupun dalam menghadapi kemajuan IPTEK sehingga matematika perlu dibekalkan pada setiap peserta didik melalui pembelajaran. Matematika diberikan dengan tujuan agar peserta didik mampu menghadapi perubahan keadaan di dunia yang selalu berkembang, melalui latihan bertindak atas dasar pemikiran secara logis, rasional, kritis, cermat, jujur dan efektif. Hal ini jelas merupakan tuntutan sangat tinggi yang tidak mungkin bisa dicapai hanya melalui hafalan, latihan pengerjaan soal yang bersifat rutin, serta proses pembelajaran biasa. Untuk menjawab tuntutan tujuan yang demikian tinggi, maka perlu dikembangkan materi serta proses pembelajarannya yang sesuai.

SMP Negeri 3 Kudus sebagai lembaga pendidikan formal dan salah satu Sekolah Menengah Pertama di Kudus, ingin menghasilkan peserta didik yang berkualitas baik dari bidang intrakulikuler maupun ekstrakulikuler. Berdasarkan hasil wawancara dengan guru Matematika yang mengajar di kelas VII SMP Negeri 3 Kudus, peserta didik banyak mengalami kesulitan dalam belajar matematika sehingga mengakibatkan rendahnya hasil belajar peserta didik terutama untuk aspek pemecahan masalah. Rata-rata hasil belajar peserta didik pada materi pokok segiempat tahun pelajaran 2007/2008 untuk aspek pemecahan masalah pada peserta didik kelas VII hanya mencapai 65. Padahal KKM yang ditetapkan pada tahun pelajaran 2007/2008 adalah 66, sedangkan tahun 2008/2009 KKM yang ditetapkan adalah 67 . Hal ini berarti bahwa pengembangan aspek pemecahan masalah masih pada tingkat yang rendah dan peserta didik belum sampai pada pengembangan berpikir kritis apalagi kemampuan memecahkan masalah. Adapun beberapa faktor yang menyebabkan rata-rata hasil belajar peserta didik masih rendah diantaranya rendahnya minat belajar peserta didik untuk mengikuti mata pelajaran matematika, peserta didik merasa matematika sulit dan peserta didik kurang aktif dalam mengikuti pembelajaran matematika.

Di SMP Negeri 3 Kudus dalam pembelajaran matematika materi pokok segiempat, guru sering memberikan contohcontoh segiempat yang berkaitan dengan kehidupan nyata, tetapi pembelajaran yang dilakukan masih menggunakan metode ekspositori. Suyitno(2004: 4) menjelaskan bahwa metode ekspositori merupakan cara penyampaian pelajaran dari guru kepada peserta didik di dalam kelas dengan cara berbicara di awal pelajaran, menerangkan materi dan contoh soal disertai tanya jawab. Ini berarti kegiatan pembelajaran masih berpusat pada guru sebagai pemberi informasi, sehingga pengetahuan yang dimiliki oleh peserta didik hanya bersifat hafalan dan tidak mendorong peserta didik untuk aktif dalam pembelajaran, sehingga hasil belajar matematika masih rendah.

Kegiatan pembelajaran KTSP lebih terpusat kepada peserta didik dan mengembangkan kreativitas peserta didik. Atas dasar itulah guru harus mampu mengadakan variasi model pembelajaran. Salah satu upaya yang dapat dilakukan agar hasil belajar peserta didik lebih baik adalah melalui pembelajaran kooperatif. Vigotsky berpendapat bahwa proses belajar akan terjadi secara efisien dan efektif apabila peserta didik belajar secara kooperatif dengan anak-anak lain dalam suasana lingkungan yang mendukung (supportive), dalam bimbingan atau pendampingan seseorang yang lebih mampu atau lebih 
dewasa, misalnya seorang guru (Lambas, 2004: 21).

Penelitian ini menggunakan model pembelajaran kooperatif tipe TAI. Pembelajaran tipe ini mengkombinasikan keunggulan pembelajaran kooperatif dan pembelajaran individual. Pembelajaran tipe ini dirancang untuk mengatasi kesulitan belajar peserta didik secara individual, sebab kegiatan pembelajarannya lebih banyak digunakan untuk pemecahan masalah (http://www.salimkita_googlegroups.com, 2008). Ciri khas pada tipe TAI ini adalah setiap peserta didik secara individual belajar materi pokok pembelajaran yang sudah dipersiapkan oleh guru. Hasil belajar individual dibawa ke kelompok-kelompok untuk didiskusikan dan saling dibahas oleh anggota kelompok, dan semua anggota kelompok bertanggung jawab atas keseluruhan jawaban sebagai tanggung jawab bersama

(http://www.salimkita_googlegroups.com, 2008). Dengan model pembelajaran kooperatif tipe TAI maka peserta didik mempunyai peluang yang cukup untuk mengoptimalkan kemampuan dalam menyerap informasi ilmiah yang dicari, dapat memotivasi peserta didik agar berperan aktif dalam pembelajaran di kelas sehingga tujuan pembelajaran dapat tercapai

Berdasarkan hasil wawancara dan pengamatan dengan guru matematika yang mengajar di SMP Negeri 3 Kudus, sebagian besar guru matematika belum pernah menggunakan media pembelajaran yang menggunakan komputer, laptop dan LCD. Dikarenakan guru tidak menguasai penggunaan komputer, laptop dan LCD dengan baik. Kemampuan guru hanya terbatas pada penguasaan Microsoft Word. Guru juga kurang familiar dengan internet. Sehingga guru tidak dapat mencari informasi tentang metode-metode terbaru pembelajaran aktif. Guru juga belum mampu menggunakan Microsoft Power Point dengan baik apalagi menggunakan Macromedia baik itu Flash, Swish ataupun Authorware. Padahal guru dituntut untuk memiliki kemampuan khusus, agar pembelajaran tidak monoton dan membosankan. Ini berarti guru belum mampu menyajikan pembelajaran yang lebih menarik.

Tujuan pendidikan matematika adalah memberikan pengetahuan pada penataan nalar, pembentuk sikap, serta memberikan tekanan pada keterampilan dalam penerapan matematika. Agar tujuan pendidikan matematika ini tercapai maka perlu disediakan fasilitas yang mendukung. Di sekolah perlu dilengkapi dengan ruang multimedia yang di dalamnya dilengkapi dengan komputer dan LCD. Dengan adanya fasilitas ini dapat membantu mendukung tercapainya pembelajaran yang efektif. Salah satu bentuk pemanfaatan komputer dan LCD dalam proses pembelajaran adalah penyampaian materi pokok dengan Macromedia Authorware.

Di SMP Negeri 3 Kudus, sudah dilengkapi ruang multimedia yang di dalamnya di lengkapi dengan komputer dan LCD. Dengan adanya fasilitas ini pembelajaran akan lebih menarik dan tidak membosankan. Akan tetapi, guru belum memanfaatkan fasilitas ini dengan baik. Ini berarti pembelajaran akan terasa kurang menarik dan membosankan. Padahal penggunaan media pembelajaran memberikan banyak manfaat, antara lain: media menghasilkan keseragaman pengamatan, media dapat menanamkan konsep dasar yang benar, konkrit, dan realistis, media membangkitkan keinginan dan minat baru, media membangkitkan motivasi dan merangsang anak untuk belajar, serta media memberikan pengalaman yang integral/menyeluruh dari yang konkrit sampai dengan abstrak (Sudrajat, 2009).

Pengembangan model pembelajaran kooperatif tipe TAI dengan menggunakan Macromedia Authorware bisa menjadi salah satu model pembelajaran yang dapat diterapkan dalam pembelajaran. Pelaksanaan model pembelajaran kooperatif tipe $T A I$ dengan menggunakan media Macromedia Authorware ini memungkinkan peserta didik 
bekerja dalam kelompok untuk memecahkan masalah sehingga peserta didik akan di tuntut berperan secara aktif dalam kelompoknya dan dalam hal ini guru berperan sebagai fasilisator dalam pembelajaran. Jadi, peserta didik akan terlibat langsung untuk membangun dan menemukan konsep-konsep sendiri agar pembelajaran lebih bermakna. Diharapkan peserta didik memahami tentang materi pokok segiempat melalui model pembelajaran kooperatif tipe $T A I$ dengan menggunakan Macromedia Authorware yang sekaligus dapat meningkatkan motivasi belajar peserta didik sehingga pada akhirnya akan memberikan akibat pada pencapaian hasil belajar yang lebih baik dan optimal terutama pada aspek pemecahan masalah.

Tujuan dalam penelitian ini adalah sebagai berikut. (1) untuk mengetahui ratarata hasil belajar matematika peserta didik yang menggunakan TAI dengan Macromedia Authorware lebih baik daripada pembelajaran tanpa Macromedia Authorware (2) untuk mengetahui hasil belajar matematika peserta didik yang menggunakan TAI dengan Macromedia Authorware akan melampaui ketuntasan klasikal yang ditetapkan oleh sekolah yaitu minimal $80 \%$ hasil belajar peserta didik mencapai 67.

Manfaat dalam penelitian ini adalah (1) Memberikan informasi mengenai penggunaan TAI dengan Macromedia Authorware terhadap hasil belajar matematika (2) meningkatkan kemampuan memecahkan masalah matematika peserta didik khususnya pada materi segiempat.

Hasil belajar merupakan perubahan tingkah laku yang baru setelah melakukan pembelajaran. Perolehan aspek-aspek perubahan perilaku tersebut tergantung pada apa yang dipelajari oleh pembelajar. Catharina (2006: 4) mengemukakan "hasil belajar merupakan perubahan perilaku yang diperoleh dari pembelajaran setelah mengalami aktivitas".

Model pembelajaran kooperatif merupakan pembelajaran yang secara sadar dan sengaja menciptakan interaksi yang saling mencerdaskan sehingga sumber belajar bagi peserta didik bukan hanya guru dan buku ajar tetapi juga sesama peserta didik. Model pembelajaran kooperatif TAI merupakan salah satu dari model pembelajaran kooperatif dengan dibentuk kelompok-kelompok kecil dalam kelas yang heterogen, terdiri dari 4-5 peserta didik dalam setiap kelompoknya dan diikuti dengan pemberian bantuan individu bagi peserta didik yang memerlukannya.

Menurut Suyitno (2004: 11), langkah-langkah model pembelajaran kooperatif tipe TAI sebagai berikut.

a. Guru menentukan suatu materi pokok yang akan disajikan.

b. Guru menjelaskan kepada seluruh peserta didik tentang TAI dan tentang pola kerjasama antara peserta didik dalam suatu kelompok.

c. Guru menyiapkan bahan dikerjakan kelompok.

d. Guru memberikan pre-test (placement test). Pre-test dapat digantikan dengan nilai rata-rata $\mathrm{UH}$. Pre-test digunakan untuk membagi dalam kelompokkelompok yang heterogen.

e. Guru menjelaskan materi baru secara singkat (teaching group).

f. Guru membentuk beberapa kelompok. Setiap kelompok terdiri dari 4-5 peserta didik dengan kemampuan yang berbeda-beda baik tingkat kemampuan (teams).

g. Guru menugasi kelompok dengan bahan/LKS, melalui kerja kelompok, peserta didik mengisi isian LKS (student creative).

h. Ketua kelompok, melaporkan keberhasilan kelompoknya atau melapor kepada guru tentang hambatan yang dialami anggota kelompoknya, jika diperlukan, guru dapat memberikan bantuan secara individual (team study).

i. Ketua kelompok harus dapat menetapkan bahwa setiap anggota telah memahami materi bahan ajar yang 
diberikan guru, dan siap untuk diberikan ulangan/quis oleh guru (Team Scores and Team Recognition).

j. Guru memberikan ulangan/quis (facts tests).

k. Guru mengumumkan hasil kerja kelompok, menetapkan kelompok terbaik dan memberikan penghargaan.

1. Menjelang akhir waktu, guru memberikan latihan pendalaman secara klasikal dengan menekankan strategi pemecahan masalah (whole-class units).

\section{Macromedia}

Authorware merupakan software yang sangat cocok untuk membuat berbagai bentuk sajian visual, baik online di Internet maupun disampaikan dalam suatu presentasi (Satya, 2002: 1). Macromedia Authorware dapat membantu anda dalam membuat suatu isi presentasi yang menarik dan enak dipandang. Dalam penelitian ini Macromedia Authorware digunakan sebagai salah satu media pembelajaran. Diharapkan dengan penggunaan program ini, peserta didik tidak bosan mengikuti pembelajaran Matematika.

Dengan Macromedia Authorware anda dapat: a) membuat media interaktif, seperti aplikasi pembelajaran untuk pendidikan, b) membuat iklan/penawaran ke relasi bisnis, konsumer dijaringan web, LAN, ataupun CD-ROM, dan c) membuat laporan ilmiah secara visual.

\section{METODE PENELITIAN}

Populasi dari penelitian ini adalah peserta didik kelas VII SMP Negeri 3 Kudus tahun pelajaran 2008/2009. Dalam penelitian ini pengambilan sampel dilakukan dengan teknik random sampling, yaitu dengan mengundi kesembilan kelas dari populasi kemudian diambil dua kelas sebagai kelas eksperimen yaitu kelas VII-F dan kelas kontrol yaitu kelas VII-D.

Variabel dalam penelitian ini adalah (1) variabel bebas yaitu penggunaan media (2) variabel terikat yaitu hasil belajar matematika peserta didik kelas VII SMP Negeri 3 Kudus materi pokok segiempat.

Desain dalam penelitian ini menggunakan satu kelas eksperimen dan satu kelas kontrol. Desain penelitian yang digunakan dapat dilihat pada tabel sebagai berikut.

Tabel1. Desain Penelitian

\begin{tabular}{|lcc|}
\hline Kelompok & Treatment & Test \\
Eksperimen & $\mathrm{X}$ & $\mathrm{T}$ \\
Kontrol & $\mathrm{Y}$ & $\mathrm{T}$ \\
\hline
\end{tabular}

Keterangan:

$\mathrm{X}$ : Pembelajaran matematika dengan TAI dengan Macromedia Authorware.

Y : Pembelajaran matematika dengan TAI tanpa Macromedia Authorware.

$\mathrm{T}$ : Tes kemampuan memecahkan masalah dalam bentuk soal uraian matematika kelas VII materi pokok segiempat.

Metode pengumpulan data dengan wawancara, dokumentasi dan tes. Teknik analisis yang dilakukukan adalah (1) data awal sebelum sampel diberi perlakuan maka perlu dianalisis dahulu melalui uji normalitas, uji homogenitas, dan uji kesamaan dua ratarata. Hal ini dilakukan supaya berangkat dari titik awal yang sama (2) Setelah kedua sampel diberi perlakuan yang berbeda, maka dilaksanakan tes akhir. Hasil tes akhir ini akan diperoleh data yang digunakan sebagai dasar dalam menguji hipotesis penelitian. Uji yang dilakukan untuk menguji keefektifan pembelajaran adalah Uji t dan Uji proporsi satu pihak.

\section{HASIL DAN PEMBAHASAN}

Hasil analisis tahap akhir yang dilakukan meliputi analisis data awal dan data akhir penelitian. Berikut ini merupakan hasil dari analisis data awal.

\begin{tabular}{ccccc}
\multicolumn{5}{c}{ Tabel 2. Hasil Uji Normalitas } \\
\hline Kelas & $\begin{array}{c}\mathrm{dk}=\mathrm{k}- \\
3\end{array}$ & $\mathrm{X}^{2}$ hitung & $\mathrm{X}^{2}$ tabel & Ket \\
& & & & \\
\hline $\begin{array}{c}\text { Eksperi } \\
\text { men }\end{array}$ & $6-3=3$ & 4,614 & 7,81 & Normal \\
\hline $\begin{array}{c}\text { Kontro } \\
1\end{array}$ & $6-3=3$ & 1,35 & 7,81 & Normal \\
\hline
\end{tabular}


Berdasarkan tabel di atas diketahui bahwa $\mathrm{X}^{2}$ hitung pada kelas eksperimen $=$ 4,614 dan $\mathrm{X}^{2}{ }_{\text {hitung }}$ pada kelas kontrol $=1,35$. Dengan $\alpha=5 \%$ dan $\mathrm{dk}=\mathrm{k}-3=6-3=3$ diperoleh $\mathrm{X}^{2}$ tabel untuk kedua kelas $=7,81$. Karena $\mathrm{X}^{2}{ }_{\text {hitung }}<\mathrm{X}^{2}$ tabel berarti $\mathrm{H}_{0}$ diterima sehingga data awal kelas eksperimen dan kelas kontrol berdistribusi normal.

Tabel 3. Hasil Uji Homogenitas

\begin{tabular}{|c|c|c|c|c|c|}
\hline Kelas & Varians & $\mathrm{N}$ & $F_{\text {hitung }}$ & $\mathrm{F}_{\text {tabel }}$ & Ket \\
\hline $\begin{array}{c}\text { Eksperi } \\
\text { men }\end{array}$ & 204,071 & 40 & \multirow{2}{*}{1,21} & \multirow{2}{*}{1,89} & \multirow{2}{*}{$\begin{array}{l}\text { Hom } \\
\text { ogen }\end{array}$} \\
\hline $\begin{array}{c}\text { Kontro } \\
1 \\
\end{array}$ & 168,342 & 40 & & & \\
\hline
\end{tabular}

Berdasarkan tabel di atas diperoleh, nilai $\mathrm{F}_{\text {hitung }}=1,21$. Dengan $\mathrm{dk}$ pembilang $=$ $40-1=39$ dan $\mathrm{dk}$ penyebut $=40-1=39$ dan taraf signifikan $5 \%$, dari daftar distribusi $\mathrm{F}$ diperoleh $F_{\text {tabel }}=1,89$. Karena $F_{\text {hitung }}<F_{\text {tabel }}$ berarti Ho diterima sehingga kedua kelompok sampel mempunyai varians yang sama atau homogen.

Pada perhitungan uji kesamaan dua rata-rata diperoleh $\mathrm{t}_{\text {hitung }}=-0,08$. Dengan $\mathrm{dk}$ $=\mathrm{n}_{1}+\mathrm{n}_{2}-2=78$ dan taraf signifikan $5 \%$ dari daftar distribusi student diperoleh $\mathrm{t}_{\text {tabel }}=1,99$. Karena- $\mathrm{t}_{\text {tabel }}<\mathrm{t}$ hitung $<\mathrm{t}$ tabel maka $\mathrm{H}_{\mathrm{o}}$ diterima, sehingga rata-rata antara kelas eksperimen dan kelas kontrol sama. data akhir.

Berikut ini merupakan hasil analisis

Tabel 4. Hasil Uji Normalitas

\begin{tabular}{ccccc}
\hline Kelas & $\begin{array}{c}\mathrm{dk}=\mathrm{k}- \\
3\end{array}$ & $\mathrm{X}^{2}$ hitung & $\mathrm{X}^{2}$ tabel & Ket \\
\hline $\begin{array}{c}\text { Eksperi } \\
\text { men }\end{array}$ & $6-3=3$ & 5,888 & 7,81 & Normal \\
\hline $\begin{array}{c}\text { Kontro } \\
1\end{array}$ & $6-3=3$ & 1,626 & 7,81 & Normal \\
\hline
\end{tabular}

Berdasarkan perhitungan di atas diperoleh $\mathrm{X}^{2}{ }_{\text {hitung }}=5,888$ pada kelas eksperimen dengan taraf signifikansi $5 \%$ dan $\mathrm{dk}=\mathrm{k}-3=6-3=3$. Dari daftar distribusi chi-kuadrat didapat $X^{2}$ tabel $=7,81$. Karena $\mathrm{X}^{2}{ }_{\text {hitung }}<\mathrm{X}^{2}{ }_{\text {tabel }}$ berarti $\mathrm{H}_{0}$ diterima sehingga data berdistribusi normal. Sedangkan pada kelas kontrol diperoleh $\mathrm{X}^{2}{ }_{\text {hitung }}=1,626$ dengan taraf signifikansi $5 \%$ dan $\mathrm{dk}=\mathrm{k}-3=6-3=3$. Dari daftar distribusi chi-kuadrat didapat $\quad \mathrm{X}_{\text {tabel }}^{2}=$ 7,81. Karena $X^{2}{ }_{\text {hitung }}<X^{2}$ tabel berarti $H_{0}$ diterima sehingga data berdistribusi normal.

Tabel 5. Hasil Uji Homogenitas

\begin{tabular}{|c|c|c|c|c|c|}
\hline Kelas & Rata-rata & Varian & $\mathrm{X}_{\text {hitung }}^{2}$ & $\mathrm{X}_{\text {tabel }}^{2}$ & Ket \\
\hline $\begin{array}{c}\text { Eksperi } \\
\text { men }\end{array}$ & 81,05 & 149,330 & \multirow{2}{*}{0,941} & \multirow{2}{*}{3,841} & \multirow{2}{*}{$\begin{array}{l}\text { Hom } \\
\text { ogen }\end{array}$} \\
\hline $\begin{array}{c}\text { Kontro } \\
1\end{array}$ & 68.34 & 204,620 & & & \\
\hline
\end{tabular}

homogenitas diperoleh $\quad \mathrm{X}_{\text {hitung }}^{2}=0,941$ dengan $\mathrm{dk}=2-1=1$ dan taraf signifikan 5\%. Dari daftar distribusi chi-kuadrat diperoleh $\quad X_{\text {tabel }}^{2}=3,841 . \quad$ Karena $\mathrm{X}_{\text {hitung }}^{2}<\mathrm{X}_{\text {tabel }}^{2}$ berarti $\mathrm{H}_{0}$ diterima sehingga kedua kelas tersebut mempunyai varians yang sama atau dapat dikatakan homogen.

Tabel 6. Hasil Uji Perbedaan Dua Rata-Rata (Uji t Pihak Kanan)

\begin{tabular}{|c|c|c|c|c|c|}
\hline Kelas & $\mathrm{N}$ & $\overline{\mathrm{X}}$ & $\mathrm{s}^{2}$ & $\mathrm{t}_{\text {hitung }}$ & $\mathrm{t}_{\text {tabel }}$ \\
\hline $\begin{array}{c}\text { Eksperim } \\
\text { en }\end{array}$ & 40 & 81,05 & 149,33 & \multirow[t]{2}{*}{4,2554} & \multirow[t]{2}{*}{1,991} \\
\hline Kontrol & 38 & 68.34 & 204,62 & & \\
\hline
\end{tabular}

dua rata-rata diperoleh $t_{\text {hitung }}=4,254$ dengan $d k=40+38-2=76$ dan taraf signifikan $5 \%$, dari daftar distribusi student diperoleh $\mathrm{t}_{\text {tabel }}=1,991$. Karena $\mathrm{t}_{\text {hitung }}>\mathrm{t}_{\text {tabel }}$ maka $\mathrm{H}_{\mathrm{o}}$ ditolak sehingga rata-rata hasil belajar matematika peserta didik yang menggunakan model pembelajaran kooperatif TAI dengan Macromedia Authorware lebih baik dibandingkan dengan peserta didik yang memperoleh pembelajaran tanpa Macromedia Authorware.

Tabel 7. Hasil Uji Proporsi Satu Pihak

\begin{tabular}{ccccc}
\hline Kelas & $\mathrm{N}$ & $\begin{array}{c}\text { Persentase } \\
\text { ketuntasan }(\pi)\end{array}$ & $\mathrm{Z}_{\text {hitung }}$ & $\mathrm{Z}_{\text {tabel }}$ \\
\hline $\begin{array}{c}\text { Eksperim } \\
\text { en }\end{array}$ & 40 & $87,5 \%$ & 1,976423544 & 1,64 \\
\hline
\end{tabular}

Dari hasil perhitungan uji proporsi satu pihak pada kelas eksperimen diperoleh $Z_{\text {hitung }}=1,976423544$, dengan taraf signifikansi $5 \%$ diperoleh $Z_{\text {table }}=Z_{(0,5-\alpha)}=$ $Z_{0,45}=1,64$. Karena $Z_{\text {hitung }} \geq Z_{\text {tabel }}$ maka Ho ditolak sehingga pengujian berarti. Jadi, hasil belajar matematika peserta didik kelas eksperimen yang menggunakan model 
pembelajaran kooperatif TAI dengan Macromedia Authorware pada materi pokok segiempat pada peserta didik kelas VII SMP Negeri 3 Kudus melampaui ketuntasan klasikal yang ditetapkan oleh sekolah yaitu minimal $80 \%$ hasil belajar peserta didik mencapai 67.

Model pembelajaran kooperatif TAI dengan Macromedia Authorware diterapkan pada kelas eksperimen, sedangkan pembelajaran yang diterapkan pada kelas kontrol adalah pembelajaran tanpa Macromedia Authorware. Model pembelajaran kooperatif TAI pada kelas eksperimen dilaksanakan dengan cara membagi peserta didik menjadi beberapa kelompok yang heterogen. Dengan menggunakan Macromedia Authorware, peserta didik akan disuguhkan sesuatu yang baru. Dengan demikian, peserta didik tidak akan merasa bosan dan makin tertarik dalam pembelajaran matematika.

Macromedia Authorware dalam penelitian ini, dibuat dalam format $C D$ Pembelajaran. Penggunaan CD pembelajaran ini sangat berguna bagi guru dan peserta dididk. Bagi guru dapat mempermudah dalam penyampaian materi pembelajaran dan bagi peserta didik dapat meningkatkan minat, motivasi, serta meningkatkan keaktifan peserta didik dalam pembelajaran. Dari hasil penelitian sebelumnya yang dilakukan oleh Puji Dwi Asih dan Kasman pada pembelajaran tanpa penggunaan $\mathrm{CD}$ pembelajaran, minat peserta didik untuk mengikuti pembelajaran cenderung rendah. Hal ini karena guru tidak menggunakan media pembelajaran sehingga pembelajaran kurang menarik dan membosankan. Faktor ini yang dapat menyebabkan rendahnya hasil belajar peserta didik. Selain itu, rendahnya hasil belajar peserta didik lebih terlihat khususnya pada materi pokok yang bersifat abstrak sehingga memerlukan visualisasi, yaitu antara lain pada materi pokok geometri diantaranya pada sub materi pokok persegi panjang dan jajargenjang. Setelah dilakukan pembelajaran dengan $\mathrm{CD}$ pembelajaran peserta didik akan lebih tertarik sehingga minat peserta didik tinggi dalam mengikuti pembelajaran, memudahkan peserta didik dalam memahami materi serta meningkatkan hasil belajar dan mutu pendidikan peserta didik.

Berdasarkan hasil penelitian pada
pertemuan pertama, pembelajaran pada pertemuan pertama berjalan cukup lancar dan menyenangkan. Macromedia Authorware yang diberikan oleh guru cukup menarik perhatian peserta didik. Tampilan warna, gambar, dan huruf pada Macromedia Authorware cukup menarik. Peserta didik cukup suka dengan tampilan pada Macromedia Authorware. Hal ini terlihat dari antusias peserta didik untuk melihat dan mendengarkan penjelasan dari guru sampai selesai. Hal ini berarti Macromedia Authorware memotivasi peserta didik untuk lebih semangat dalam mengerjakan tugas-tugas yang diberikan oleh guru terutama dalam mengerjakan LKS yang telah dipersiapkan guru. Dengan Macromedia Authorware peserta didik menjadi lebih memperhatikan penjelasan dari guru.

Secara umum pada pertemuan kedua ini pembelajaran berjalan lebih baik daripada pertemuan sebelumnya. Peserta didik makin suka dengan tampilan Macromedia Authorware karena tampilan warna, gambar, dan huruf pada Macromedia Authorware cukup menarik minat peserta didik untuk melihatnya sampai selesai. Peserta didik makin antusias dan tertarik pada Macromedia Authorware yang diberikan oleh guru. Karena sebelumnya guru belum pernah menyampaikan materi dengan menggunakan media pembelajaran, sehingga peserta didik kurang tertarik dalam pembelajaran.

Penjelasan tentang materi yang diberikan oleh guru dan cara pemecahan masalah sudah baik, proses diskusi berjalan lancar tetapi presentasi beberapa kelompok di depan kelas masih belum disertai tanya jawab dari keompok lain. Hal ini karena peserta 
didik masih malu untuk bertanya, sedangkan untuk kemampuan guru dalam pembelajaran juga mengalami peningkatan. Hal ini dimungkinkan karena guru sudah mulai terbiasa dengan suasana kelas dan juga alokasi waktu yang sudah direncanakan secara matang.

Pelaksanaan pembelajaran pada pertemuan ketiga berjalan lebih baik daripada pertemuan sebelumnya. Macromedia Authorware yang diberikan oleh guru cukup menarik perhatian peserta didik, terutama karena tampilan warna, gambar, dan huruf pada Macromedia Authorware dibuat semenarik mungkin. Peserta didik makin menikmati pembelajaran menggunakan Macromedia Authorware.

Pada pertemuan ketiga peserta didik aktivitas peserta didik makin meningkat. Peserta didik sudah dapat menyesuaikan diri dengan anggota kelompok yang lain. Peserta didik sudah terbiasa dengan model pembelajaran yang diterapkan. Aktivitas peserta didik kali ini lebih baik, interaksi antar anggota kelompok juga terjalin dengan baik. Guru juga menghargai jawaban peserta didik sehingga banyak peserta didik yang merespon pertanyaan lisan dari guru. Peserta didik yang belum paham terhadap hasil diskusi kelompok lain yang disajikan di depan kelas sudah banyak yang berani untuk bertanya maupun menyanggah hasil diskusi yang tidak sesuai dengan temuan kelompoknya. Pembelajaran pada pertemuan ketiga dapat berlangsung dan selesai sesuai dengan waktu yang dialokasikan.

Presentasi di depan kelas oleh perwakilan kelompok sudah lebih baik dari pertemuan sebelumnya. Karena suara yang dikeluarkan saat menjelaskan hasil diskusi kelompok sudah cukup keras sehingga peserta didik yang duduk di belakang bisa mendengar penjelasan dari kelompok yang mempresentasikan. Karena penyajian hasil diskusi dengan suara yang jelas, maka peserta didik yang menanggapi jawaban dan bertanya meningkat. Pada saat guru memberikan penjelasan, peserta didik juga banyak yang bertanya apabila belum paham.

Secara umum pelaksanaan pembelajaran pada pertemuan keempat berjalan dengan baik dan menyenangkan. Peserta didik sangat menikmati pembelajaran dengan Macromedia Authorware. Hal ini berarti peserta didik suka dengan Macromedia Authorware yang diberikan oleh guru baik itu dari segi tampilan warna, gambar, maupun huruf. Macromedia Authorware dibuat semenarik mungkin agar peserta didik tertarik dalam pembelajaran Matematika. Peserta didik sangat bersemangat dalam pembelajaran. Peserta didik juga sangat antusias dalam pembelajaran pertemuan keempat ini. Berdasarkan hasil wawancara dengan peserta didik, peserta didik tidak merasa bosan dan lebih semangat dalam mengerjakan tugastugas yang diberikan oleh guru. Hal ini berarti pembelajaran dengan Macromedia Authorware dapat meningkatkan motivasi belajar peserta didik.

Pelaksanaan pembelajaran pada pertemuan keempat jauh lebih baik dibandingkan pertemuan-pertemuan sebelumnya baik aktivitas peserta didik maupun aktivitas guru. Guru sudah membimbing peserta didik dengan baik dalam memecahkan masalah-masalah yang tertuang dalam LKS, sehingga pembelajaran menjadi kondusif dan tidak terjadi kegaduhan yang mengganggu diskusi kelompok. Guru selalu berkeliling mengawasi jalannya diskusi, memberikan bimbingan kepada kelompok yang mengalami kesulitan. Selain itu guru juga memberikan bantuan secara individual pada peserta didik yang masih mengalami kesulitan. Aktivitas peserta didik yang meningkat ditunjukkan dengan hampir seluruh peserta didik melakukan kegiatan matematis. Tidak ada peserta didik yang diam atau berbicara sendiri. Interaksi antar peserta didik sudah baik, mereka saling bekerjasama dan berdiskusi. Peserta didik menjadi lebih berani dan tidak malu-malu 
lagi dalam mempresentasikan hasil karya di depan kelas.

Diakhir pertemuan guru selalu memberikan penghargaan kepada kelompok yang mendapat skor tertinggi dalam mengerjakan LKS 1. Pemeberian penghargaan ini bisa berupa pujian, tepuk tangan dari seluruh kelas maupun berupa hadiah.

Soal-soal pemecahan masalah yang harus diselesaikan peserta didik juga meningkatkan motivasi untuk terus belajar agar dapat menyelesaikan permasalahan yang dihadapi dalam kehidupan sehari-hari. Konsep yang diperoleh peserta didik dari hasil penemuan, mencoba-coba, diskusi dan bekerjasama dengan teman lain membuat peserta didik lebih mampu memaknai pengetahuan yang diperoleh. Peserta didik berkerjasama untuk menyelesaikan LKS yang dirancang oleh guru. Guru telah memberikan langkah-langkah pemecahkan masalah dalam LKS tersebut. Hal ini membantu peserta didik agar lebih mudah memahami langkah-langkah yang benar dalam memecahkan masalah. Dan juga sebagai bekal untuk mengerjakan kuis yang akan diberikan oleh guru untuk mengetahui keberhasilan pembelajaran pada tiap pertemuan. Peningkatan kemampuan peserta didik juga diikuti oleh peningkatan kemampuan guru dalam mengelola pembelajaran. Kamampuan guru mengelola pembelajaran mengalami peningkatan pada setiap pembelajaran. Kekurangan, hambatan dan kendala yang ada pada setiap pembelajaran harus ditindaklanjuti. Karena itu guru perlu terus memperbaiki kekurangan dan kesalahan pada pembelajaran sebelumnya.

Pada kelas kontrol diterapkan model pembelajaran kooperatif TAI tanpa Macromedia Authorware. Secara umum pembelajaran yang dilakukan hampir sama dengan pembelajaran pada kelas eksperimen, tetapi pembelajaran pada kelas kontrol tidak menggunakan Macromedia Authorware. Tidak digunakannya Macromedia
Authorware menjadi hambatan dalam pembelajaran yaitu peserta didik kurang tertarik dan merasa bosan dalam pembelajaran. Pada pertemuan pertama ini peserta didik kurang tertarik dan bosan dalam pembelajaran. Hal ini dikarenakan tidak diberikannya media pembelajaran sebagai variasi dalam pembelajaran. Peserta didik masih malu dan tidak mau bertanya saat mengalami kesulitan. Peserta didik juga belum berani mengungkapkan pendapat dan kebanyakan masih bergantung pada ketua kelompok. Karena kesulitan yang dialami peserta didik maka guru harus memberikan penjelasan berulang-ulang sehingga pembelajaran tidak selesai tepat sesuai waktu yang dialokasikan.

Pengelolaan pembelajaran pada kelas kontrol pertemuan pertama secara umum cukup berjalan lancar, tetapi peserta didik masih kesulitan menjawab masalah-masalah yang ada pada LKS 1. Kesulitan yang dihadapi disebabkan karena kurangnya kesiapan belajar peserta didik untuk bertanya kepada guru atau sesama anggota kelompok jika mengalami kesulitan. Selain itu peserta didik kurang tertarik dalam pembelajaran, sehingga mereka kurang besemangat dalam mengerjakan tugas-tugas yang diberikan oleh guru.

Pada pertemuan kedua pembelajaran berlangsung cukup lancar dibandingkan pertemuan pertama. Aktivitas peserta didik sedikit demi sedikit mulai meningkat. Tetapi masih ada peserta didik yang kurang tertarik dalam pembelajaran akibatnya peserta didik hanya bergantung pada ketua kelompok. Peserta didik sudah tidak malu lagi untuk bertanya kepada guru jika mengalami kesulitan, tetapi masih ada peserta didik yang masih malu. Beberapa peserta didik juga menganggap materi ini masih terlalu sulit karena mereka jarang menerapkan rumus yang mereka dapatkan untuk menyelesaikan masalah dalam kehidupan sehari-hari seperti yang ada pada LKS 2 . 
Pada pertemuan ketiga, peserta didik sudah dapat menyesuaikan diri cukup baik dalam pembelajaran. Aktivitas peserta didik mulai meningkat, interaksi antar anggota kelompok sudah terjalin dengan baik.. Dalam hal ini guru membimbing peserta didik untuk memecahkan masalah baik secara individual maupun klasikal. Peserta didik terlihat sudah terbiasa dengan pembelajaran yang diterapkan, sehingga pada saat menyelesaikan LKS 3 yang diberikan oleh guru, peserta didik sudah tidak mengalami kesulitan.

Pada pertemuan keempat ini pembelajaran berlangsung baik. Peserta didik dapat mengungkapkan pendapat dan berdiskusi dengan anggota kelompoknya jika mengalami kesulitan. Masalah-masalah yang terdapat dalam LKS 4 dapat diselesaikan dengan baik. Peserta didik sudah tertarik dan menikmati pembelajaran yang diberikan oleh guru. Pada pertemuan ini aktivitas peserta didik lebih baik dari pertemuan sebelumnya.

Setelah kedua kelompok diberi perlakuan yang berbeda, peserta didik dari kedua kelas tersebut diberi tes kemampuan pemecahan masalah yang sama. Pelaksanaan tes dilakukan pada hari yang sama. Kemudian hasil tes tersebut dianalisis dengan statistik yang sesuai untuk mengetahui keefektifan pembelajaran model pembelajaran kooperatif TAI dengan Macromedia Authorware. Indikator dari efektivitas pembelajaran model pembelajaran kooperatif TAI dengan Macromedia Authorware adalah rata-rata hasil belajar matematika peserta didik yang menggunakan model pembelajaran kooperatif TAI dengan Macromedia Authorware lebih baik daripada pembelajaran tanpa Macromedia Authorware dan hasil belajar matematika peserta didik yang menggunakan model pembelajaran kooperatif TAI dengan Macromedia Authorware akan melampaui ketuntasan klasikal yang ditetapkan oleh sekolah yaitu minimal $80 \%$ hasil belajar peserta didik mencapai 67.
Pada kelas eksperimen diberi perlakuan model pembelajaran kooperatif TAI dengan Macromedia Authorware dan kelas kontrol pembelajaran tanpa Macromedia Authorware, terlihat bahwa hasil belajar kedua kelompok tersebut berbeda secara nyata. Berdasarkan perhitungan dari hasil belajar matematika materi pokok segiempat diperoleh rata-rata kelompok eksperimen 81,05 dan kelompok kontrol 68,34. Berdasarkan pengujian hipotesis dengan menggunakan uji beda dua rata-rata satu pihak yaitu pihak kenan diperoleh hasil bahwa rata-rata hasil belajar matematika peserta didik yang menggunakan model pembelajaran kooperatif TAI dengan Macromedia Authorware lebih baik dibandingkan dengan peserta didik yang menggunakan pembelajaran tanpa Macromedia Authorware.

Keefektifan model pembelajaran kooperatif TAI dengan Macromedia Authorware juga dilihat dari hasil belajar peserta didik pada kelas eksperimen telah melampaui ketuntasan klasikal yang ditetapkan oleh sekolah yaitu minimal $80 \%$ hasil belajar peserta didik mencapai 67 . Berdasarkan pengujian hipotesis dengan uji proporsi satu pihak diperoleh hasil bahwa hasil belajar peserta didik kelas eksperimen yang menggunakan model pembelajaran kooperatif TAI dengan Macromedia Authorware lebih dari atau sama dengan ketuntasan klasikal yang ditetapkan oleh sekolah yaitu minimal $80 \%$ hasil belajar peserta didik mencapai 67.

Berdasarkan uraian di atas diketahui bahwa rata-rata hasil belajar matematika peserta didik yang menggunakan model pembelajaran kooperatif TAI dengan Macromedia Authorware lebih baik daripada pembelajaran tanpa Macromedia Authorware dan hasil belajar matematika peserta didik yang menggunakan model pembelajaran kooperatif TAI dengan Macromedia Authorware melampaui ketuntasan klasikal yang ditetapkan oleh sekolah yaitu $80 \%$. Dengan kata lain, model pembelajaran 
kooperatif

Teams

Individualization

(TAI)

Assisted

dengan

Macromedia Authorware materi pokok segiempat pada peserta didik kelas VII SMP Negeri 3 Kudus efektif dibandingkan dengan pembelajaran tanpa Macromedia Authorware.

\section{KESIMPULAN}

Berdasarkan hasil penelitian yang telah di lakukan di SMP Negeri 3 Kudus kelas VII tahun pelajaran 2008/2009 dan pembahasan pada bab IV maka dapat disimpulkan bahwa model pembelajaran kooperatif TAI dengan Macromedia Authorware efektif terhadap hasil belajar matematika dibandingkan dengan pembelajaran tanpa Macromedia Authorware pada materi pokok segiempat dikarenakan. (1) Rata-rata hasil belajar matematika peserta didik yang memperoleh pembelajaran menggunakan model pembelajaran kooperatif TAI dengan Macromedia Authorware lebih baik daripada pembelajaran tanpa Macromedia Authorware pada materi pokok segiempat pada peserta didik kelas VII SMP Negeri 3 Kudus (2) Hasil belajar matematika peserta didik yang memperoleh pembelajaran menggunakan model pembelajaran kooperatif TAI dengan Macromedia Authorware pada materi pokok segiempat pada peserta didik kelas VII SMP Negeri 3 Kudus melampaui ketuntasan klasikal yang ditetapkan oleh sekolah yaitu minimal 80 $\%$ hasil belajar peserta didik mencapai 67 .

\section{DAFTAR PUSTAKA}

Anni Catharina, Tri. 2006. Psikologi Belajar. Semarang: UNNES PRESS.

Arifin, Zaenal. 1991. Evaluasi Instruksional, Prinsip-teknikprosedur. Bandung:Remaja Rosdakarya.
Arikunto, Suharsimi. 2002. Dasar-Dasar Evaluasi Pendidikan. Jakarta: Bumi Aksara.

Hamalik, Oemar. 2007. Proses Belajar Mengajar. Jakarta: Bumi aksara.

Ibrahim, Muslimin. 2000. Pembelajaran Kooperatif. Surabaya: UNESA.

Kasman. 2008. Keefektifan Media Video Compact Disc Disertai Lembar Kerja Siswa Terhadap Kemampuan Pemecahan Masalah Matematika Siswa Kelas X. Semarang: FMIPA UNNES.

Mulyasa. 2007. Kurikulum Tingkat Satuan Pendidikan. Bandung: Remaja Rosdakarya.

Puji Dwi Asih. 2008. Keefektifan Pembelajaran Dengan Bantuan CD Interaktif Terhadap Hasil Belajar Dalam Materi Luas Permukaan Dan Volum Kubus Dan Balok Siswa SMP Negeri 1 Rembang Kelas VIII Semester 2 Tahun Pelajaran 2007/2008. Semarang: FMIPA UNNES.

Sadiman, dkk. 2002. Media Pendidikan. Jakarta: PT Raja Grafindo Persada.

Satya Adi S, Heribertus. 2002. Macromedia Authorware 6. Yogyakarta: ANDI.

Shadiq, Fadjar. 2005. Pemecahan Pembelajaran dan Penerapannya di Sekolah. Semarang: UNNES.

Slavin, Robert. E. 2008. Cooperative Learning. Bandung: Nusa Media.

Sudjana. 2002. Metoda Statistika. Bandung: Tarsito. 
Sugiarto dan Hidayah, Isti. 2007. Workshop Pendidikan Matematika II. Semarang: Jurusan Matematika FMIPA UNNES.

Sugiarto, dkk. 2001. Teknik Sampling. Jakarta: PT Gramedia Pustaka Utama.

Sugiyono. 2005. Statistika untuk Penelitian. Bandung: Alfabeta.

Suherman, Erman. 2003. Strategi Pembelajaran Matematika Kontemporer. Bandung: Jurusan Pendidikan Matematika Fakultas Pendidikan Matematika dan Ilmu Pengetahuan Alam Universitas Pendidikan Indonesia.

Suyitno, Amin. 2004. Dasar-Dasar Dan Proses Pembelajaran Matematika. Semarang: UNNES.
Suyitno, Amin 2004. Makalah Pendidikan Pemilihan Model-Model Masalah dalam Pembelajaran Matematika. Dalam Materi Pembinaan Matematika SMP. Tim PPPG Yogyakarta. Hal 39-45.

\section{SUMBER INTERNET}

http://zainurie.wordpress.com. 15 Mei 2009.

http://akhmadsudrajat.wordpress.com. 2 Mei 2009.

http://www.geocities.com/teknologipembel ajaran/ktsp.html. 27 Januari 2009.

http://www.salimkita_googlegroups.com. 5 Desember 2008. 